\title{
Penggunaan Milrinon pada Pasien dengan Sindrom Eisenmenger yang Menjalani Operasi Seksio Sesarea
}

\author{
Anggara Gilang Dwiputra ${ }^{1 *}$, Ratna Farida Soenarto ${ }^{1}$
}

1. Departemen Anestesiologi dan Terapi Intensif, Fakultas Kedokteran Universitas Indonesia, RSUPN Dr. Cipto Mangunkusumo, Jakarta, Indonesia

\begin{abstract}
ABSTRAK
Sindrom Eisenmeger adalah kelainan jantung dengan karakteristik hipertensi pulmonal yang disertai pirau kanan ke kiri ataupun dua arah, akibat jangka panjang defek septum interventrikel atau patent ductus arteriosus (PDA) yang tidak diterapi. Kehamilan sulit ditoleransi pada pasien dengan sindrom Eisenmenger dimana mortalitas ibu mencapai 30-50\%. Perubahan fisiologis menurunkan tahanan vaskular sistemik yang memperburuk pirau.2 Seksio Sesarea merupakan pilihan teknik persalinan pada kondisi tersebut. Kami melaporkan dua pasien dengan sindrom Eisenmenger yang berhasil menjalani seksio sesarea dengan anestesi umum. Anestesi umum dilakukan dengan teknik titrasi dan menggunakan obat dengan pengaruh minimal terhadap sistem kardiovaskular. Selama operasi pasien diberikan milrinon yang dikombinasikan dengan agen katekolamin. Pascaoperasi pasien dirawat di ICU. Selama perawatan di ICU tidak ada komplikasi signifikan yang terjadi. Pasien pertama berhasil pindah ke ruang rawat pada hari ke-3 pascaoperasi, sedangkan pasien ke-2 pindah pada hari ke-7 pascaoperasi. Tujuan manajemen anestesi pada pasien sindrom Eisenmenger adalah mempertahankan SVR, menjaga kecukupan volume intravaskular dan mencegah peningkatan lebih jauh PVR. Penggunaan milrinon yang dikombinasikan dengan agen katekolamin dapat membantu tercapainya tujuan tersebut sehingga dapat memperbaiki oksigenasi dan mempertahankan hemodinamik pasien. Walaupun kehamilan pada pasien Eisenmenger tidak dianjurkan, namun persalinan melalui seksio Sesarea masih dapat dilakukan dengan manajemen yang baik.
\end{abstract}

Kata Kunci: hipertensi pulmonal, milrinon, seksio Sesarea, sindrom Eisenmenger 


\title{
The Use of Milrinone for Patients with Eisenmenger Syndrome Undergoing Caesarean Section
}

\author{
Anggara Gilang Dwiputra ${ }^{1 *}$, Ratna Farida Soenarto ${ }^{1}$
}

1. Departement of Anesthesiology and Intensif Care, Faculty of Medicine, Universitas Indonesia, Dr. Cipto Mangunkusumo National General Hospital, Jakarta, Indonesia

*corresponding author

\begin{abstract}
Eisenmenger's syndrome is defined as pulmonary hypertension with right to left or bidirectional shunt, associated with untreated ventricular septal defect or patent ductus arteriosus.1 Pregnancy is poorly tolerated in patients with Eisenmenger's syndrome with maternal mortality of 30-50\%. Physiological changes decreases systemic vascular resistance (SVR) that further aggravates the shunt. 2 Caesarean section is the preferred technique of delivery in such condition. We report two Eisenmenger's syndrome patients who underwent successful Caesarean section under general anesthesia. General aensthesia is performed by means of a titratin technique, using drugs with minimal effect on the cardiovascular system. During the operation, the patients are given milrinone combined with a catecholamine agent. Postoperatively the patients are admitted to the ICU. There were no significant complications occurred in the ICU. The first patient was successdully transferred to the ward on the 3rd postoperative day, while the second patient moved on the 7 th postoperative day. The goals of anesthesia management in Eisenmenger'a syndrome patients are to maintain a stable SVR, maintain adequate intravascular volume, and prevent further increases in PVR. The use of milrinone in combination with catecholamine agents can help achieve these goals so as to improve oxygenation and maintain patient hemodynamics. Although pregnancy in Eisenmenger's patient is not recommended, delivery by Caesarean section can still be done with good management.
\end{abstract}

Keywords: Caesarean section, Eisenmenger's syndrome, milrinone, pulmonary hypertension 


\section{PENDAHULUAN}

Selama kehamilan terjadi perubahan fisiologis yang meliputi penurunan systemic vascular resistance (SVR), peningkatan volume darah dan peningkatan sekunder cardiac output (CO) akibat peningkatan laju jantung dan stroke volume (SV). ${ }^{1-3}$ Pasien dengan penyakit jantung tidak dapat beradaptasi dengan baik terhadap perubahan fisiologis tersebut, terutama pasien dengan sindrom Eisenmenger.

Sindrom Eisenmenger merupakan salah satu kondisi kelainan jantung dengan karakteristik pirau (shunt) dari kanan ke kiri ataupun dua arah akibat hipertensi pulmonal berat. Kondisi ini merupakan patofisiologi lanjut pirau kiri ke kanan (defek septum interventrikel atau Patent Ductus Arteriosus/PDA) yang tidak dikoreksi. Sindrom ini diperkenalkan pada tahun 1897 dan didefinisikan ulang oleh Wood pada tahun 1958. ${ }^{1}$ Mortalitas pada ibu dan janin sangat tinggi dengan risiko kumulatif sebesar 30$50 \%$. Kematian dapat terjadi kapanpun selama kehamilan hingga masa nifas. ${ }^{4}$

Persalinan pada ibu hamil dengan sindrom Eisenmenger dapat dilakukan melalui persalinan per vaginam atau seksio Sesarea. ${ }^{5,6}$ Manajemen anestesi pada ibu hamil dengan sindrom Eisenmenger yang menjalani seksio Sesarea selalu menjadi suatu tantangan dalam bidang anestesiologi. Baik anestesi umum maupun regional dapat dilakukan sebagai teknik pilihan, selama dapat mempertahankan tahanan vaskular sistemik tidak turun dan mencegah naiknya tahanan vaskular pulmonal.

Penggunaan vasodilator pulmonal selama perioperatif dapat dipertimbangkan karena dari laporan kasus yang ada, pemberian obat vasodilator pulmonal berhubungan dengan luaran yang baik. ${ }^{7}$ Vasodilator yang disarankan untuk pasien dengan hipertensi pulmonal adalah golongan obat prostanoid, endothelin receptor antagonist (ERA), dan inhibitor fosfodiesterase. ${ }^{8}$ Milrinon merupakan golongan obat inhibitor bipiridin fosfodiesterase III yang memiliki efek inotropik positif dan vasodilator. Karena karakteristik tersebut, milrinon diindikasikan sebagai obat penopang jantung pada pasien dengan gagal jantung akut, hipertensi pulmonal, atau gagal jantung kronik. Milrinon sering digunakan baik pada pasien dengan gagal jantung ventrikel kiri akut, gagal jantung ventrikel kanan akut atau pun hipertensi arteri pulmonal yang menjalani operasi jantung maupun operasi nonjantung. ${ }^{9}$

Berikut merupakan dua laporan kasus manajemen pasien dengan sindrom Eisemenger yang menjalani seksio Sesarea dengan anestesi umum. Kedua kasus berikut menggunakan milrinon sebagai salah satu obat rumatan selama operasi.

\section{ILUSTRASI KASUS}

\section{Kasus 1}

Perempuan, 26 tahun, datang ke IGD dengan keluhan sesak napas berat. Pasien didiagnosis dengan G2P1 hamil 35 minggu, congestive heart failure functional class III-IV, Atrial Septal Defect (ASD) dan sindrom Eisenmenger. Pada pemeriksaan fisik didapatkan laju nadi 95x/ mnt, tekanan darah $117 / 75 \mathrm{mmHg}$, laju napas 34-36x/mnt, saturasi oksigen $78-80 \%$ dengan nasal kanul $3 \mathrm{lpm}$, dan pansistolik murmur. Hasil ekokardiografi didapatkan ASD sekundum dengan pirau dua arah, fungsi ventrikel kanan dan kiri normal (EF: 72\%, TAPSE $21 \mathrm{~mm}$ ), regurgitasi pulmonal sedang, regurgitasi trikuspid berat dan hipertensi pulmonal berat. Pasien direncanakan operasi seksio Sesarea.

Saat tiba di kamar operasi, pasien dipasang CVC dan arterial line. Nilai awal tekanan vena sentral yang terukur adalah sebesar $12 \mathrm{cmH} 2 \mathrm{O}$. Obat rumatan diberikan berupa milrinon 0,2 $\mathrm{mcg} / \mathrm{kg} / \mathrm{mnt}$ dan norepinefrin $0,05 \mathrm{mcg} / \mathrm{kg} /$ mnt via CVC. Induksi anestesi umum dilakukan dengan memberikan fentanyl $100 \mathrm{mcg}(2 \mu \mathrm{g} / \mathrm{kg})$, ketamin $50 \mathrm{mg}(1 \mathrm{mg} / \mathrm{kg})$, sevofluran 1,5 vol\% dan rokuronium $50 \mathrm{mg}(1 \mathrm{mg} / \mathrm{kg})$. Sevofluran $1-1,5 \%$ vol\% diberikan sebagai rumatan anestesi. Empat menit setelah operasi dimulai, bayi lahir dengan skor Apgar 7/9 dan tidak memerlukan resusitasi aktif. Kemudian pasien diberikan oksitosin $20 \mathrm{IU}$ yang didrip dalam $100 \mathrm{~mL} \mathrm{NaCl}$ 0,9\% (kecepatan 2-5 IU/jam) dan furosemid 20 $\mathrm{mg}$ intravena untuk mengantisipasi overload cairan.

Operasi berlangsung selama 1 jam, dengan total perdarahan $500 \mathrm{~mL}$, cairan masuk 500 $\mathrm{mL}$, urin output $1 \mathrm{~mL} / \mathrm{kg} / \mathrm{jam}$. Hemodinamik pasien selama operasi stabil dengan saturasi oksigen berkisar $84-86 \%$ dan tekanan vena 
sentral berkisar antara 11-14 cmH2O. Kemudian pasien dipindahkan ke ICU. Selama perawatan di ICU pasien tetap mendapat milrinon 0,2 mcg/ $\mathrm{kg} / \mathrm{mnt}$. Pasien diekstubasi keesokan harinya dan pindah ke ruang rawat pada hari ke-3 pascaoperasi.

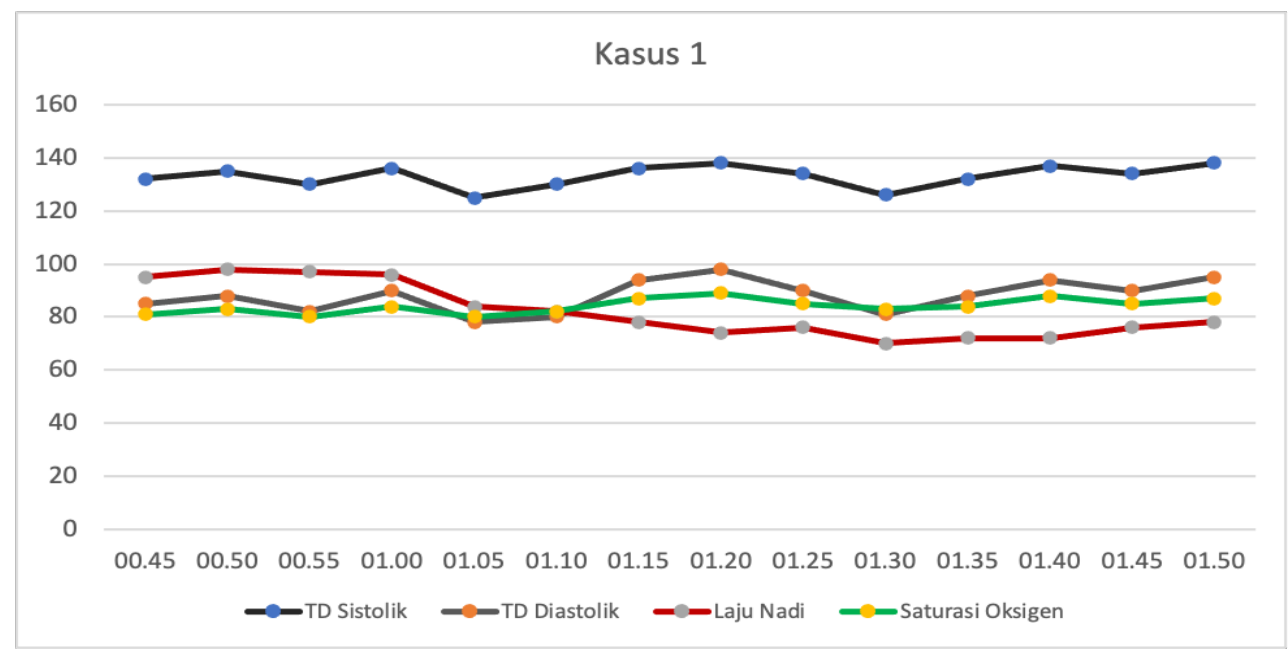

Gambar 1. Tanda-tanda Vital Pasien Kasus 1

Kasus 2

Perempuan, 39 tahun dengan diagnosis congestive heart failure functional class III-IV dan sindrom Eisenmenger pada G5P4 hamil 32 minggu direncanakan operasi seksio Sesarea. Pasien mengeluh sesak yang memberat sejak satu minggu sebelum masuk rumah sakit tanpa keluhan demam, batuk, pilek atau nyeri dada.

Dari pemeriksaan fisik didapatkan tekanan darah $120 / 80 \mathrm{mmHg}$, laju nadi 90x/mnt, laju napas $30 \mathrm{x} / \mathrm{mnt}$, saturasi oksigen $85 \%$ dengan nonrebreathing mask $10 \mathrm{lpm}$, murmur pansistolik, suara gallop, ronki basah halus dan mengi di kedua paru, edema tungkai bilateral dan clubbing finger. Hasil ekokardiografi didapatkan dilatasi atrium kanan dan ventrikel kanan, regurgitasi trikuspid sedang-berat, hipertensi pulmonal berat, atrial septal defect (ASD), fungsi sistolik kiri sulit dinilai, fungsi sistolik kanan masih baik (TAPSE $22 \mathrm{~mm}$ ).

Saat tiba di kamar operasi, pasien dipasang CVC dan arterial line. Tekanan vena sentral praoperasi sebesar $9 \mathrm{cmH} 2 \mathrm{O}$. Milrinon mulai diberikan dengan dosis $0,375 \mathrm{mcg} / \mathrm{kg} /$ menit dan dopamin diberikan dengan dosis titrasi mulai dari $3 \mathrm{mcg} / \mathrm{kg} / \mathrm{menit}$ melalui CVC. Induksi anestesi dilakukan dengan fentanyl $200 \mathrm{mcg}$, ketamin $20 \mathrm{mg}$ dan sevofluran 2 vol\%. Intubasi

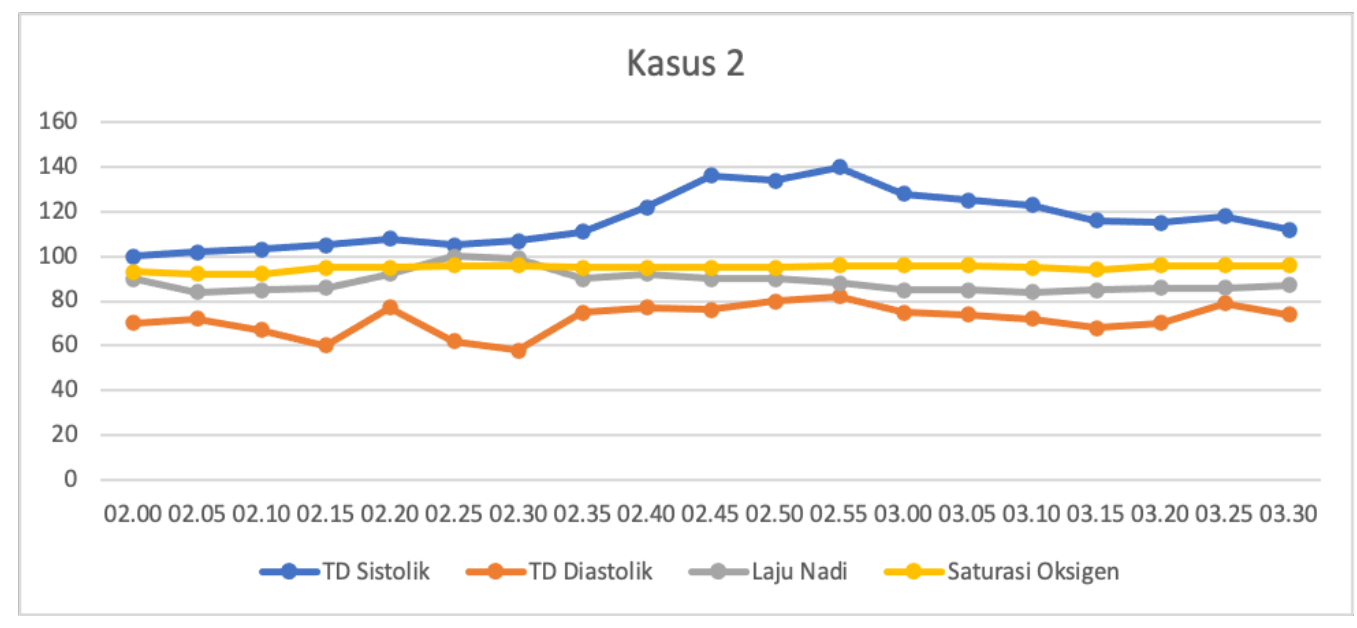

Gambar 2. Tanda-tanda Vital Pasien Kasus 2 
difasilitasi dengan rokuronium $50 \mathrm{mg}$. Pasien dihubungkan dengan ventilator dengan mode volume control, volume tidal $350 \mathrm{~mL}$, laju napas 12x/mnt, PEEP: off, fraksi oksigen $60 \%$. Rumatan anestesi dengan sevofluran 1 vol\%.

Lima menit setelah operasi dimulai, bayi lahir dengan skor APGAR 2/8. Kemudian pasien diberikan oksitosin $20 \mathrm{IU}$ dalam $100 \mathrm{ml} \mathrm{NaCl}$ $0,9 \%$ dan furosemid $10 \mathrm{mg}$.

Operasi berlangsung selama 45 menit dengan hemodinamik pasien yang relatif stabil, saturasi oksigen berkisar 92-96\%, tekanan vena sentral berkisar antara $8-12 \mathrm{cmH}_{2} \mathrm{O}$. Total cairan masuk $100 \mathrm{~mL}$ kristaloid, perdarahan $300 \mathrm{~mL}$, produksi urin $100 \mathrm{~mL}$.

Pascaoperasi pasien dipindahkan ke ICU. Milirinon dan dopamin tetap diberikan selama perawatan di ICU. Pasien sempat memiliki tanda-tanda infeksi, namun membaik dengan pemberian antibiotik. Pada perawatan hari ke-5 pasien diekstubasi dan pindah ke ruang rawat pada hari ke-7 pascaoperasi.

\section{DISKUSI}

Sindrom Eisenmenger didefinisikan sebagai hipertensi pulmonal yang disertai pirau kanan ke kiri ataupun dua arah, sebagai patofisiologi lanjut defek septum ventrikel atau PDA yang tidak dikoreksi. ${ }^{10}$ Pada saat kehamilan terjadi perubahan fisiologis di berbagai sistem organ, terutama sistem kardiovaskular, yang meliputi penurunan SVR, peningkatan volume darah dan peningkatan sekunder $\mathrm{CO}$ akibat peningkatan laju jantung dan SV. ${ }^{3}$ Volume darah dapat meningkat sebesar $10 \%$ di trimester pertama hingga $45 \%$ saat trimester ketiga. Saat dan segera setelah persalinan, kontraksi uterus dan dekompresi aortokaval menyebabkan tambahan volume darah hingga 1,5 L. ${ }^{11}$ Pada kondisi normal, peningkatan volume tersebut dapat dikompensasi dengan vasodilatasi di pembuluh darah sistemik dan pulmonal. Namun, pada pasien dengan sindrom Eisenmenger peningkatan pulmonary vascular resistance (PVR) yang ireversibel tidak dapat memfasilitasi perubahan volume darah, selain itu penambahan volume darah pada kondisi hipertensi pulmonal berat dan penurunan SVR dapat meningkatkan pirau kanan ke kiri sehingga memperburuk hipoksia, yang kemudian memicu lingkaran setan dimana terjadi peningkatan lebih lanjut hipertensi pulmonal, regangan ventrikel kanan dan pirau kanan ke kiri. Ventrikel kanan yang sudah teregang akan semakin besar regangannya karena penurunan suplai oksigen akibat hipoksemia yang memberat dan tekanan arterial sistemik yang menurun. Peningkatan volume darah pada ibu hamil dengan sindrom Eisenmenger dapat meningkatkan risiko terjadinya gagal jantung ventrikel kanan. ${ }^{12}$

Kehamilan pada pasien dengan sindrom Eisenmenger memiliki risiko kematian dan persalinan prematur yang sangat tinggi. Abortus spontan terjadi pada $20-30 \%$ kehamilan dan persalinan prematur terjadi pada hampir separuhnya. Hampir separuh dari seluruh neonatus yang lahir mengalami retardasi pertumbuhan intrauterin. Kematian ibu intrapartum atau dalam periode satu minggu postpartum terjadi pada $30-45 \%$ kehamilan. Persalinan yang sukses pada kehamilan pertama tidak menyingkirkan kemungkinan kematian ibu pada kehamilan selanjutnya. ${ }^{13}$

Periode persalinan merupakan saat yang kritis bagi wanita dengan penyakit jantung karena perubahan hemodinamik yang mendadak dapat menyebabkan dekompensasi. Hipovolemia akibat perdarahan atau hipotensi akibat respons vasovagal terhadap nyeri dapat menyebabkan kematian mendadak. Kontraksi uterus, nyeri, cemas dan upaya mengejan dapat meningkatkan laju jantung dan tekanan darah sehingga membebani sistem kardiovaskular yang sudah terganggu. Curah jantung meningkat dari 15\% pada awal persalinan hingga $50-60 \%$ selama upaya mengejan dan mencapai $80 \%$ segera pada masa postpartum karena berkurangnya obstruksi vena kava inferior. Setiap kontraksi uterus meningkatkan curah jantung sebanyak $20 \%$ melalui autotransfusi darah. Semua proses tersebut dapat menyebabkan gagal jantung dan kongesti paru akut. Selain itu, kematian juga dapat terjadi akibat tromboemboli paru atau infark paru in situ. ${ }^{5,14}$

Angka mortalitas antara persalinan per vaginam dan seksio Sesarea tidak jauh berbeda. Keduanya memiliki angka mortalitas yang lebih tinggi bermakna daripada abortus spontan. Tindakan seksio Sesarea lebih dipilih daripada 
persalinan per vaginam karena persalinan dapat dilakukan secara elektif pada kondisi paling optimal dan dapat mencegah stres dan nyeri berkepanjangan. ${ }^{6,13,15}$

Pembiusan pada pasien dengan sindrom Eisenmenger merupakan suatu tantangan bagi anestesiologis. Tujuan manajemen anestesi adalah menjaga CO stabil tanpa memperparah pirau kanan ke kiri dengan cara menjaga SVR dan kecukupan volume intravaskular serta mencegah meningkatnya PVR. ${ }^{12}$ Baik anestesi regional maupun anestesi umum dapat dipilih, dengan risiko dan keuntungannya masingmasing. Pada anestesi umum, ventilasi tekanan positif intermiten secara teoritis dapat menyebabkan penurunan venous return dan CO serta peningkatan tekanan arteri pulmonal, yang dapat meningkatkan pirau kanan ke kiri. Namun, anestesi umum telah dilaporkan berhasil digunakan pada pasien sindrom Eisenmenger yang akan menjalani operasi seksio Sesarea. ${ }^{1}$ Anestesi regional dengan spinal atau epidural dapat menurunkan SVR. ${ }^{10}$ Teknik untuk menurunkan stimulasi simpatis seringkali juga menurunkan SVR sehingga dapat meningkatkan pirau kanan ke kiri. ${ }^{12}$

Pada laporan kasus ini, anestesi umum dipilih karena pasien sesak saat diposisikan berbaring terlentang dan untuk mencegah penurunan drastis SVR akibat anestesi regional. Selain itu dengan anestesi umum kadar $\mathrm{CO} 2$, kadar O2, nyeri dan peningkatan PVR dapat dikendalikan. Pada saat induksi tidak dilakukan rapid sequence induction (RSI) melainkan dengan koinduksi opioid, ketamin dan anestetik volatil sevofluran untuk mencegah terjadinya gangguan hemodinamik akibat penurunan drastis SVR. Intubasi difasilitasi rokuronium yang memiliki onset cepat untuk mengurangi risiko aspirasi.

Pengunaan N2O dihindari karena merupakan vasokonstriktor pulmonal poten. ${ }^{4}$ Pemeliharaan anestesi dengan sevofluran 0,5 hingga 1 vol\% untuk mencegah terjadinya atonia uteri. Mode ventilasi diupayakan dengan pemberian tekanan inspirasi yang tidak berlebih untuk mencegah hiperinflasi paru dan peningkatan PVR.

Pemantauan tekanan darah dilakukan secara kontinyu melalui jalur intra-arteri. Kateter arteri pulmonal tidak dipasang untuk menghindari aritmia yang disebabkan kateter, salah posisi kateter, terbentuknya trombus, embolisasi dan ruptur arteri pulmonal karena adanya hipertensi pulmonal. Akses vena sentral dipasang untuk mendeteksi gagal jantung kanan dan untuk mengoptimalkan preload ${ }^{1}$ di samping sebagai fasilitas pemberian obat kardiovaskular.

Milrinon, yang memiliki efek inodilator, diberikan dengan tujuan memperbaiki kontraktilitas jantung kanan dan menurunkan PVR. Walaupun milrinon termasuk golongan obat kategori C, namun pada dasarnya tidak ada kontraindikasi penggunaan milrinon pada ibu hamil. ${ }^{16}$ Pada penelitian di hewan coba, milrinon tidak memiliki efek samping terhadap aliran darah uterus dan hemodinamik janin. ${ }^{17}$ Milrinon merupakan obat golongan inhibitor fosfodiesterase III bipiridin, yang diindikasikan untuk penopang jantung pada pasien dengan gagal jantung akut, hipertensi pulmonal atau gagal jantung kronik. Milrinon dapat memperbaiki kontraktilitas jantung, relaksasi jantung dan memicu vasodilatasi. ${ }^{9}$

Milrinon bekerja dengan menghambat fosfodiesterasetipe 3, enzimyangmemetabolisme cyclic adenosine monophosphate. Dengan meningkatkan cyclic adenosine monophosphate, kalsium intraselular bertambah, sehingga meningkatkan kontraktilitas miokardium. Selain itu, milrinon juga meningkatkan relaksasi diastolik mikoardium dengan meningkatkan laju reuptake kalsium setelah sistolik (lusitropik). ${ }^{9}$ Studi McNamara pada pasien neonatus dengan persistent pulmonary hypertension of the newborn (PPHN), menunjukan bahwa milrinon dapat meningkatkan oksigenasi tanpa mengganggu tekanan darah sistemik. Hal tersebut karena efek vasodilator pulmonal dan kardiotropik dari milrinon. ${ }^{18}$

Pemberian milrinon perlu diwaspadai karena milrinon memiliki efek hipotensi sistemik, sehingga seringkali diberikan bersama dengan agen katekolamin yang memiliki efek agonis $\alpha_{1}$-adrenergik. Kombinasi agen katekolamin bersama dengan inhibitor fosfodiesterase dapat mencegah efek samping terkait dosis masingmasing obat dan bermanfaat pada kasus gagal ventrikel kanan. ${ }^{19}$

Pada kasus pertama agen katekolamin yang dipilih adalah norepinefrin, sedangkan kasus kedua yang dipilih adalah dopamin. Kedua obat tersebut bekerja di reseptor $\alpha$-adrenergik dan 
memiliki efek vasokonstriksi.

Norepinefrin adalah katekolamin endogen yang memiliki aktivitas $\alpha$-adrenergik dengan efek ringan hingga sedang pada reseptor $\beta$-adrenergik. Afinitas norepinefrin terhadap reseptor $\alpha$-adrenergik yang tinggi menghasilkan efek vasokonstriktor yang kuat, tetapi efek inotropik dan kronotropiknya lebih lemah. Norepinefrin sering digunakan dengan milrinon dan dobutamin untuk melawan vasodilatsi sistemik dan hipotensi pada pasien setelah cardiopulmonary bypass (CPB). ${ }^{19}$ Dari beberapa penelitian yang meneliti efek norepinefrin pada ibu dan janin, didapatkan hasil bahwa norepinefrin aman dan efektif diberikan pada pasien hamil yang mengalami hipotensi tanpa menimbulkan efek samping yang signifikan. ${ }^{20,21}$ Norepinefrin memiliki karakteristik onset yang cepat dan durasi yang singkat, sehingga memungkinkan pemberian titrasi secara akurat. $^{20}$

Dopamin merupakan obat vasoaktif yang bekerja pada reseptor $\alpha$-adrenergik, $\beta$-adrenergik, dopaminergik dan juga bekerja melepaskan norepinefrin. Pada dosis $2-10 \mathrm{mcg} / \mathrm{kg} / \mathrm{menit}$, reseptor $\beta 1$ terstimulasi sehingga kontraktilitas dan curah jantung meningkat. Selain itu pada dosis $\geq 5 \mathrm{mcg} / \mathrm{kg} /$ menit terjadi pelepasan norepinefrin endogen. Pada dosis yang lebih besar, $10-20 \mathrm{mcg} / \mathrm{kg} / \mathrm{menit}$, reseptor $\alpha$ dan $\beta_{1}$ terstimulasi didominasi efek vasokonstriksi $\alpha$ adrenergik, tetapi perfusi renal berkurang. ${ }^{14,22}$

Bertambahnya volume plasma secara progresif selama kehamilan dan autotransfusi darah akibat kontraksi uterus saat persalinan meningkatkan preload dan membebani ventrikel kanan sehingga dapat mencetuskan gagal jantung kanan. Furosemid diberikan setelah bayi lahir untuk menurunkan beban jantung kanan akibat perubahan fisiologis tersebut.

Literatur menunjukkan bahwa angka mortalitas ibu dalam periode satu minggu postpartum tinggi yaitu $30-45 \%$ meskipun selama periode intraoperasi tidak terdapat masalah yang signifikan. Oleh karena itu, pascaoperasi pasien dirawat di ICU untuk pemantauan hemodinamik ketat dan kemungkinan terjadinya perburukan pirau atau kejadian tromboemboli pascaoperasi. ${ }^{1,2}$ Pada laporan kasus ini, pascaoperasi kedua pasien ditransfer ke ICU untuk observasi ketat. Selama perawatan di ICU keduanya tetap mendapat drip milrinon 0,2 $\mathrm{mcg} / \mathrm{kg} / \mathrm{menit}$. Hemodinamik pasien pertama cukup stabil dan dapat diekstubasi satu hari pascaoperasi, kemudian pindah ke ruang rawat pada hari ketiga. Sedangkan pada pasien kedua baru dapat pindah ke ruang rawat pada hari ketujuh karena saat perawatan di ICU terdapat gejala demam dan leukosit yang meningkat, sehingga dicurigai terdapat infeksi. Setelah mendapat antibiotik, tanda-tanda infeksi pada pasien membaik, dan pasien dapat diekstubasi pada hari kelima.

\section{SIMPULAN}

Tujuan manajemen anestesi pada pasien sindrom Eisenmenger adalah mempertahankan SVR, menjaga kecukupan volume intravaskular dan mencegah meningkatnya PVR agar pirau kanan ke kiri tidak bertambah. Penggunaan milrinon yang dikombinasikan dengan agen katekolamin dapat membantu tercapainya tujuan tersebut sehingga dapat memperbaiki oksigenasi dan mempertahankan hemodinamik pasien. Walaupun kehamilan pada pasien Eisenmenger tidak dianjurkan, namun dengan manajemen yang baik persalinan melalui sektio Sesarea masih dapat dilakukan.

\section{DAFTAR PUSTAKA}

1. Kandasamy R, Koh KF, Tham SL, Reddy S. Anaesthesia for caesarean section in a patient with Eisenmenger's syndrome. Singapore Med J. 2000;41(7):356-8.

2. Hussain AM, Ismail S, Kamal RS. General anaesthesia for emergency caesarian section in a patient with Eisenmenger's syndrome and pre-eclampsia. J Pak Med Assoc. 2005;55(8):348-50.

3. Fang G, Tian YK, Mei W. Anaesthesia management of caesarean section in two patients with Eisenmenger's syndrome. Anesthesiol Res Pract. 2011;2011(55 mm):15.

4. Gurumurthy T, Hegde R, Mohandas BS. Anaesthesia for a patient with Eisenmenger's syndrome undergoing caesarean section. Indian J Anaesth. 2012;56(3):291-4.

5. Borges $V$, Magalhães $C$, Martins A, Matsubara 
B. Eisenmenger syndrome in pregnancy. Arq Bras Cardiol. 2008;90(5):39-40.

6. Mordechai R Kramer DR. Pulmonary hypertension and pregnancy: management and outcome. J Pulm Respir Med. 2013;

7. Kurniawaty J. Manajemen peripartum pada pasien sindrom Eisenmenger. J Komplikasi Anestesi. 2018;5(3):29-37.

8. Effendi R. Sindrom eissenmenger dan tantangan anestesi. BioTrends. 2018;9(2):5668.

9. Ayres J, Maani C. Milrinone. Treasure Island: Statpearls Publishing; 2020.

10. Dasgupta S, Das S, Majumdar B, Basu SM. Caesarean section in Eisenmenger's syndrome: Anaesthetic management with titrated epidural and nebulised alprostadil. South African J Anaesth Analg [Internet]. 2016;22(2):65-7. Available from: http:// dx.doi.org/10.1080/22201181.2016.114543 2

11. Kopec G. Pregnant woman with Eisenmenger. J Rare Cardiovasc Dis. 2013;1(3):113-7.

12. Minicucci S, Segala V, Verdecchia C, Sismondi $P$, Casabona R, Sansone F. Safe management of cesarean section in a patient of Eisenmenger syndrome. Ann Card Anaesth. 2012;15(4):296-8.

13. Baum V, De Souza D. Congenital heart disease in adults. In: Kaplan J, Augoustides J, Manecke Jr. G, Maus T, Reich D, editors. Kaplan's Cardiac Anesthesia for Cardiac and Noncardiac Surgery. 7th ed. Philadelphia: Elsevier; 2017. p. 827-8.

14. Glick D. The Autonomic nervous system. In: Miller R, Cohen N, Eriksson L, Fleisher L, Wiener-Kronish J, Young W, editors. Miller's Anesthesia. 8th ed. Philadelphia: Elsevier Saunders; 2015. p. 365-8.

15. Ruys T, Cornette J, Roos-Hesslink J. Pregnancy and delivery in cardiac disease. J Cardiol. 2013;61(2):107-12.
16. Scardovi AB, De Maria R. Peripartum cardiomyopathy: challenges and solutions. Res Reports Clin Cardiol. 2017; Volume 8:3140.

17. Santos AC, Baumann AL, Wlody D, Pedersen $\mathrm{H}$, Morishima HO, Finster M. The maternal and fetal effects of milrinone and dopamine in normotensive pregnant ewes. Am J Obstet Gynecol [Internet]. 1992;166(1 PART 1):257-62. Available from: http://dx.doi. org/10.1016/0002-9378(92)91869-C

18. McNamara $P$, Laique $F$, Muang-In S, Whyte $\mathrm{H}$. Milrinone improves oxygenation in neonates with severe persistent pulmonary hypertension of the newborn. J Crit Care. 2006;21(2):217-22.

19. Levy J, Ghadimi K, Bailey J, Ramsay J. Postoperative cardovascular management. In: Kaplan J, Augoustides J, Jr GM, Maus T, Reich D, editors. Kaplan's Cardiac Anesthesia for Cardiac and Noncardiac Surgery. 7th ed. Philadelphia: Elsevier; 2017. p. 1327-39.

20. Wang X, Shen X, Liu S, Yang J, Xu S. The Efficacy and Safety of Norepinephrine and Its Feasibility as a Replacement for Phenylephrine to Manage Maternal Hypotension during Elective Cesarean Delivery under Spinal Anesthesia. Biomed Res Int. 2018;2018.

21. Xu S, Shen X, Liu S, Yang J, Wang X. Efficacy and safety of norepinephrine versus phenylephrine for the management of maternal hypotension during cesarean delivery with spinal anesthesia : A systematic review and meta-analysis. Med (United States). 2019;98(5):1-9.

22. Royster R, Groban L, Locke A, Morris B, Slaughter T. Cardiovascular pharmacology. In: Kaplan J, Augoustides J, Jr GM, Maus T, Reich D, editors. Kaplan's Cardiac Anesthesia for Cardiac and Noncardiac Surgery. 7th ed. Philadelphia: Elsevier; 2017. p. 331-2. 